\title{
Analisis Pengelolaan Dana Kas Kecil pada PT Bank Negara Indonesia (Persero) Tbk KCU Magelang
}

\author{
Febriyanti Rizqi Wulandari \\ Universitas Tidar \\ febriyantirizqi4@gmail.com
}

\section{Nibras Anny Khabibah \\ Universitas Tidar \\ nibras@untidar.ac.id}

\begin{abstract}
Abstrak Penelitian ini bertujuan untuk menganalisis pengelolaan dana kas kecil di PT Bank Negara Indonesia (Persero) Tbk KCU Magelang. Jenis penelitian adalah deskriptif kualitatif dengan teknik pengumpulan data observasi dan wawancara dengan instrumen penelitian berupa pedoman wawancara dan pedoman dokumentasi. PT Bank Negara Indonesia (Persero) Tbk KCU Magelang menggunakan Persekot sebagai pembentukan dana kas kecil. Metode yang digunakan adalah metode dana kas kecil imprest. Karena menggunakan Persekot, perlakuan pembukuannya sedikit berbeda dengan pembukuan dana kas kecil pada umumnya. Dalam menggunakan Persekot beserta laporan pertanggungjawaban penggunaan Persekot (Reimbursement) harus mendapat persetujuan dari pihak yang berwenang di dalam perusahaan agar tidak menjadi beban bagi perusahaan. Dengan kata lain, jika laporan pertanggungjawaban penggunaan Persekot (Reimbursement) tidak disetujui otoritas, otomatis akan membebani kerugian perusahaan. Hal inilah yang menjadi dasar pengendalian internal yang paling penting guna mengurangi atau meminimalisir terjadinya kerugian perusahaan akibat tidak disetujuinya laporan pertanggungjawaban penggunaan Persekot (Reimbursement).
\end{abstract}

Kata Kunci Dana Kas Kecil, Persekot, PT Bank Negara Indonesia (Persero) Tbk KCU Magelang

\section{PENDAHULUAN}

Cash (kas) merupakan komponen penting dalam siklus operasional suatu perusahaan. Setiap perusahaan pasti dibentuk bagian kas, dan bagian kas akan dibantu bagian petty cash ( kas kecil) yang ditanda tangani oleh petugas pelaksanaan petty cash dan fungsi-fungsi bersangkutan untuk membantu kinerja operasional langsung. Transaksi yang terjadi tidak begitu rumit namun harus melakukan pengelolaan secara baik dan teliti berdasarkan prosedur operasi pelaksanaan dana perusahaan yang ada. Pengelolaan dana kas kecil yang tidak memadai atau cenderung buruk dapat mengganggu kelancaran operasional perusahaan. 
Kas kecil merupakan dana khusus yang dibentuk organisasi untuk membiayai pengeluaran organisasi yang sifatnya kecil atau sehari-hari. Dana kas kecil (petty cash) dibentuk berdasarkan perkiraan pengeluaran biaya operasional perusahaan, Contohnya biaya yang dikeluarkan untuk membayar tekening listrik, telepon, trasportasi, biaya keamanan dan biaya-biaya lainnya. Selain untuk membayar pengeluaran-pengeluaran perusahaan yang jumlah nominalnya kecil, pembentukan petty cash juga bertujuan untuk membayar pengeluaran yang sifatnya mendadak dan sebagai dana langsung untuk jenisjenis pembayaran yang tidak praktis apabila menggunakan cek.

PT Bank Negara Indonesia (Persero) Tbk KCU Magelang merupakan salah satu bank konvensional yang berada di wilayah Magelang. Dalam pelaksanaan operasional perusahaan diatur oleh peraturan pemerintah. Semua yang tertuang dalam peraturan pemerintah tersebut harus dilakukan seluruh bank konvensional termasuk PT Bank Negara Indonesia (Persero) Tbk KCU Magelang dan seluruh kantor cabang di Indonesia.

PT Bank Negara Indonesia (Persero) Tbk menjalankan aktivitas operasional perusahaannya dengan menggunakan sistem uang muka operasional yang diterapkan juga di PT Bank Negara Indonesia (Persero) Tbk KCU Magelang. Seluruh kegiatan operasional yang rutin dari pengeluaran kecil seperti ATK, Konsumsi Rapat Kerja, Perbaikan Gedung Kantor, dan lain-lain atau bisa dikatakan sebagai pengeluaran kas kecil di PT Bank Negara Indonesia (Persero) Tbk KCU Magelang dibiayai dengan Uang Muka yang disebut dengan Persekot. Sesuai dengan peraturan operasional perusahaan bahwa Persekot dapat dicairkan untuk mengelola operasional perusahaan dan membiayai pengeluaran-pengeluaran perusahaan yang sifatnya kecil atau sedikit.

Pada PT Bank Negara Indonesia (Persero) Tbk KCU Magelang seluruh biaya operasional yang relatif kecil dan biaya promosi atau dengan kata lain secara umum dibentuk oleh kas kecil tetapi diperlakukan lain yaitu dengan uang muka operasional/Persekot. Hal ini didasarkan pada salah satu peraturan operasional perusahaan yang mewajibkan adanya Persekot untuk membiayai operasional perusahaan yang relatif kecil. Dengan mempertimbangkan bahwa Persekot tersebut mudah dicairkan oleh PT Bank Negara Indonesia (Persero) Tbk KCU Magelang melalui Teller yang dipinjamkan sebagai uang muka operasional. Maka dalam penelitian ini difokuskan untuk mengamati dan mendalami pembentukan dana kas kecil yang dibiayai dengan uang muka operasional/persekot. Kemudian yang lebih difokuskan lagi ketika uang muka operasional/persekot tersebut dianggap seperti utang dan harus dikembalikan karena sistemnya mengambil dari uang yang ada di Teller yang seakan-akan dipinjamkan sebagai Uang Muka.

Dalam hal ini pengendalian internal menjadi penting karena memastikan penganggaran dan pertanggung jawaban uang muka tesebut. Pengendalian internal sangat dibutuhkan di setiap perusahaan guna mengatur internal perusahaan. Setiap perusahaan pasti memiliki masalah internal yang tidak dapat dihindari, sehingga diperlukan adanya pengendalian intern. Pengendalian intern dimaksud untuk mencegah terjadinya kecurangan-kecurangan oleh pihak karyawan sendiri dalam perusahaan atau dimaksudkan untuk mengamankan serta melindungi kekayaan perusahaan (Mahfiza, 2018).

\section{LANDASAN TEORI}

Dalam sebuah perusahaan, fungsi dana kas kecil sangatlah penting karena sifatnya 
yang dapat digunakan untuk kepentingan yang mendesak dan segera. Oleh karena itu perusahaan sering menggunakan dana kas kecil untuk memenuhi pengeluaran operasional yang relatif kecil guna menunjang keefektifan dan kelancaran perusahaan.

\section{Penggunaan Persekot sebagai Kas Kecil}

Menurut Soemarso (2004:135) kas kecil adalah sebagai sejumlah uang tunai tertentu yang disisihkan dalam perusahaan dan digunakan untuk melayani pengeluaranpengeluaran tertentu. Biasanya pengeluaran-pengeluaran yang dilakukan melalui dana kas kecil adalah pengeluaran pengeluaran yang jumlahnya tidak besar (Grahito \& , 2015). Sedangkan pengertian Persekot itu sendiri adalah uang muka atau uang panjar atas penyerahan barang atau jasa yang harus dipertanggungjawabkan penerima pada suatu tanggal kemudian.

Pengelolaan kas kecil pada PT Bank Negara Indonesia (Persero) Tbk KCU Magelang menggunakan sistem uang muka operasional yang disebut Persekot. Persekot digunakan untuk membiayai seluruh operasional perusahaan yang relatif kecil dan bersifat segera. Persekot tersebut digunakan untuk membiayai operasional perusahaan selama satu minggu. Dalam setiap penggunaan Persekot harus disertai dengan bukti-bukti transaksi yang nantinya digunakan sebagai bukti dalam pencatatan atau penjurnalan transaksi dalam kartu kontrol (Control Card). Persekot ini memiliki batas maksimal penyelesaian selama 10 hari kerja. Penyelesaian Persekot dilakukan dengan cara mengumpulkan, mengelompokkan, kemudian menjurnal atau mencatat bukti transaksi ke dalam pos-pos beban sesuai dengan jenis transaksi.

\section{Pengendalian Internal Kas Kecil}

Kas merupakan salah satu harta perusahaan yang sangat penting karena dalam menjalankan usahanya setiap perusahaan selalu membutuhkan uang kas untuk membiayai kegiatan perusahaan sehari-hari. Kas dalam neraca merupakan aktiva yang paling likuid karena hampir setiap transaksi yang dilakukan oleh fungsi yang berwenang atau yang terkait di dalam perusahaan maupun dengan pihak luar yang sebagian besar akan mempengaruhi kas. Selain itu kas bersifat mudah dipindahtangankan sehingga kas merupakan aktiva yang sangat diperhatikan karena mudah digelapkan dan dimanipulasi (Rivai \& Pratiwi, 2016).

Setiap perusahaan pada umumnya mengadakan pengawasan yang ketat terhadap kas untuk menghindari terjadinya penggelapan kas atau penyimpangan yang mencolok terhadap kas. Keadaan ini akan mendorong perusahaan untuk melakukan sistem pengendalian intern terhadap kas. Menurut Mulyadi (2008:165) sistem pengendalian intern adalah sistem pengendalian intern meliputi struktur organisasi, metode dan ukuranukuran yang dikoordinasikan untuk menjaga kekayaan organisasi, mengecek ketelitian dan kehandalan data akuntansi, mendorong efesiensi dan mendorong dipatuhinya kebijakan menajemen.

Berbagai macam pengendalian internal kas kecil atau Persekot yang diterapkan di PT Bank Negara Indonesia (Persero) Tbk KCU Magelang guna meminimalkan tindak kecurangan atau penyimpangan. Pengendalian internal Persekot dilakukan dengan melakukan penyelesaian Persekot sebelum 10 hari kerja. Mengingat bahwa Persekot memiliki batas maksimal penyelesaian selama 10 hari kerja. Jika selama 10 hari kerja Persekot tidak dapat diselesaikan akan berdampak pada meningkatnya beban bank yang 
tidak dianggarkan sebelumnya sehingga akan menimbulkan overbudget. Selain itu, pengambilan uang Persekot harus dilakukan oleh Asisten Administrasi Umum atas persetujuan Supervisor Administrasi Umum dan Pimpinan Kantor Cabang. Penggunaan Persekot harus diawasi oleh Supervisor Administrasi Umum dan disertai nota-nota sebagai bukti atas penggunaan uang Persekot tersebut. Pengendalian intern yang paling utama yaitu dalam penggunaan Persekot beserta laporan pertanggungjawaban atas penggunaan Persekot (Reimbursement) tersebut harus disetujui oleh pihak yang berwenang dalam perusahaan agar tidak menjadi beban kerugian perusahaan.

\section{METODOLOGI PENELITIAN}

Jenis penelitian yang dipakai adalah deskriptif. Indrawan \& Yaniawati (2014:56) menyatakan jika data deskriptif biasanya digabungkan lewat susunan pertanyaan dan survey, wawancara, maupun observasi. Survey pada penelitian ini dilakukan secara langsung di PT Bank Negara Indonesia (Persero) Tbk KCU Magelang. Wawancara serta observasi juga dilakukan dengan informan yang terkait dengan PT Bank Negara Indonesia (Persero) Tbk KCU Magelang. Objek penelitian yang dipilih yaitu PT Bank Negara Indonesia (Persero) Tbk KCU Magelang yang beralamat di Jl. Pahlawan No.1, Magelang, Kec. Magelang Tengah, Kota Magelang, Jawa Tengah 56117. Waktu penelitian dilaksanakan pada tanggal 13 Januari 2020 sampai 13 Februari 2020.

Sesuai dengan penelitian yang diambil yakni "Analisis Pengelolaan Dana Kas Kecil di PT Bank Negara Indonesia (Persero) Tbk KCU Magelang”, target/subjek utama dalam penelitian ini adalah pengelolaan dana kas kecil yang terdapat di PT Bank Negara Indonesia (Persero) Tbk KCU Magelang. Teknik analisis yang digunakan yaitu teknik deskriptif yang fungsinya menggambarkan mengenai sasaran yang diteliti yang mana teknik analisis ini diawali dengan pengidentifikasian jalannya pengelolaan dana kas kecil di PT Bank Negara Indonesia (Persero) Tbk KCU Magelang. Selain itu juga memakai instrumen pembantu seperti notebook, media berbentuk audio/video, kamera yang digunakan sebagai pendokumentasian kegiatan serta laptop untuk menyusun hasil akhir penelitian.

\section{HASIL PENELITIAN}

\subsection{Mekanisme Uang Muka/Persekot dan Perlakuan Akuntansi sampai pada tahap penggunaan Uang Muka/Persekot.}

Dana kas kecil (petty cash fund) selalu dibentuk oleh perusahaan, hal ini dikarenakan banyak kebutuhan-kebutuhan yang sifatnya kecil yang tidak praktis jika dibayar dengan menggunakan cek. Begitu juga dengan PT Bank Negara Indonesia (Persero) Tbk KCU Magelang, perusahaan ini menyediakan dana kas kecil untuk membayar pengeluaran-pengeluaran operasional yang sifatnya kecil dan segera.

Pada PT Bank Negara Indonesia (Persero) Tbk KCU Magelang dana kas kecil dibentuk dengan uang muka atau disebut dengan Persekot. Persekot ini digunakan untuk membiayai pengeluaran operasional bank seperti Beban ATK, Beban Rapat Kerja, Beban Perbaikan Gedung Kantor, dan lain-lain. Persekot diambil dari dana kas kecil yang diambil dari Teller yang dipinjamkan sebagai uang muka operasional. Persekot tersebut dapat dicairkan selama satu minggu sekali sebesar Rp15.000.000,00 - Rp20.000.000,00 atau sesuai dengan kebutuhan pengeluaran operasional perusahaan. Prosedur penganggaran persekot dilakukan dengan meminjam kas dari Teller setiap satu minggu 
sekali yang dilakukan oleh Asisten Administrasi Umum dengan persetujuan dari Supervisor Administrasi Umum dan Pimpinan Kantor Cabang. Untuk penyelesaian persekot tersebut dilakukan setiap akhir minggu dengan disertai nota-nota bukti penggunaan kas dan voucher yang dilampirkan. Apabila uang persekot tersebut sisa atau tidak terpakai semua maka sisa uang tersebut dikembalikan ke Teller.

Perlakuan akuntansi pada persekot ini menggunakan metode beban yang ditangguhkan. Dalam hal ini, bahwa dana kas kecil yang digunakan dalam PT Bank Negara Indonesia (Persero) Tbk KCU Magelang menggunakan metode imprest. Metode imprest atau imprest fund system adalah metode pembukuan kas kecil di mana rekening kas kecil jumlahnya selalu tetap. Setiap pengeluaran kas terjadi, pemegang petty cash tidak serta merta langsung mencatatnya, tetapi hanya sekedar mengumpulkan bukti transaksi pengeluarannya. Ketika sisa uang Persekot serta bukti atas penggunaannya dikembalikan baru dijurnal berdasarkan transaksi sesuai dengan pos-pos beban yang sudah ditetapkan. Kondisi tersebut termasuk ke dalam pengelolaan dan pengendalian dana kas kecil. Pengelolaan dan pengendalian dana kas kecil ini berfungsi untuk mengelola pengeluaran operasional perusahaan dan meminimalkan terjadinya kesalahan pencatatan atau tindak kecurangan oleh pihak-pihak yang terlibat atas dasar bukti-bukti atas penggunaan uang Persekot.

Penggunaan Persekot tersebut harus disetujui terlebih dahulu oleh Supervisor Administrasi Umum selaku pemimpin bidang Administrasi Umum. Seperti penggunaan Persekot untuk BBM kendaraan oleh driver maka harus mengisi kas bon dan meminta tandatangan Supervisor Administrasi Umum, jika disetujui maka Asisten Administrasi Umum akan memberikan Persekot sesuai dengan angka yang tercantum kepada driver. Kemudian driver harus memberikan nota sebagai bukti penggunaan Persekot tersebut kepada Asisten Administrasi Umum yang nantinya akan digunakan sebagai acuan pembuatan jurnal dan voucher dalam melakukan penyelesaian Persekot. Jika Persekot tersebut digunakan untuk membiayai pengeluaran divisi lain seperti event yang disupport oleh PT Bank Negara Indonesia (Persero) Tbk KCU Magelang, maka untuk penyelesaian Persekot harus terlebih dahulu membuat Surat Reimbursement yang disetujui oleh pimpinan divisi tersebut.

Pada minggu pertama bulan Februari 2019, Asisten Administrasi Umum PT Bank Negara Indonesia (Persero) Tbk KCU Magelang membentuk dana kas kecil atau yang disebut dengan Persekot yang akan digunakan untuk membayar pengeluaran-pengeluaran tunai yang tidak besar jumlahnya dan sering terjadi. Disepakati bahwa Persekot yang dibentuk sebesar Rp5.000.000, yang akan diselesaikan dan diisi kembali setiap akhir minggu. Selama minggu pertama bulan Februari 2019, transaksi PT Bank Negara Indonesia (Persero) Tbk KCU Magelang yang menggunakan Persekot adalah sebagai berikut :

3/2/2019 Membeli peralatan tulis kantor sebesar Rp1.050.000,00

4/2/2019 Membeli bensin untuk kendaraan kantor sebesar Rp125.000,00

5/2/2019 Membayar tagihan listrik kantor sebesar Rp1.125.000,00

5/2/2019 Membayar tagihan materai sebesar Rp450.000,00

6/2/2019 Membayar tagihan air sebesar Rp750.000,00

Jurnal umum yang diperlukan menyangkut penggunaan Persekot dengan metode imprest adalah sebagai berikut : 


\begin{tabular}{|c|c|c|c|}
\hline $3 / 2 / 2019$ & $\begin{array}{r}\text { Persekot } \\
\text { Kas }\end{array}$ & Rp10.000.000,00 & Rp10.000.000,00 \\
\hline \multirow[t]{2}{*}{$3 / 2 / 2019$} & Beban ATK & Rp1.050.000,,00 & \\
\hline & Persel & & Rp1.050.000,00 \\
\hline \multirow[t]{2}{*}{$4 / 2 / 2019$} & Beban BBM & Rp125.000,00 & \\
\hline & Persel & & Rp125.000,00 \\
\hline \multirow[t]{2}{*}{$5 / 2 / 2019$} & Beban Listrik & Rp1.125.000,00 & \\
\hline & Persel & & Rp1.125.000,00 \\
\hline \multirow[t]{2}{*}{$5 / 2 / 2019$} & Beban Mater & iRp450.000,00 & \\
\hline & Persel & & Rp450.000,00 \\
\hline \multirow[t]{2}{*}{$6 / 2 / 2019$} & Beban Air & Rp750.000,00 & \\
\hline & Persel & & Rp750.000,00 \\
\hline \multirow[t]{2}{*}{$7 / 2 / 2019$} & Kas & Rp10.000.000,00 & \\
\hline & Persel & & Rp10.000.000,00 \\
\hline
\end{tabular}

\subsection{Pengendalian Internal Uang Muka/Persekot sampai tahap Pelaporan Pertanggungjawaban.}

Sistem Pengendalian Internal memiliki peranan penting bagi sebuah perusahaan karena sistem pengendalian intern merupakan prosedur atau sistem yang dirancang untuk mengontrol, mengawasi, mengarahkan organisasi agar dapat mencapai suatu tujuan. Sistem tersebut dapat digunakan oleh manajemen untuk merencanakan dan mengendalikan operasi perusahaan, membantu menyediakan informasi akuntansi yang handal untuk laporan keuangan, dan menjamin dipatuhinya hukum dan peraturan yang berlaku.

Dalam penggunaan Persekot dalam pemenuhan dana kas kecil tentunya memiliki kelebihan dan kelemahan. Kelebihannya yaitu dengan adanya Persekot maka perusahaan dapat dengan mudah membiayai pengeluaran operasional yang relatif kecil pada saat itu juga. Selain itu, dengan metode pencatatan transaksi yang diterapkan akan meminimalkan resiko terjadinya kecurangan. Kelemahannya yaitu jika laporan pertanggungjawaban atas penggunakan Persekot (Reimbursement) tidak disetujui oleh pihak yang berwenang, misalnya kepala bagian divisi maka penggunaan Persekot tersebut menjadi beban kerugian perusahaan.

Persekot ini memiliki batas maksimal penyelesaian selama 10 hari kerja. Jika selama 10 hari kerja tersebut Persekot tidak dapat diselesaikan atau tidak mendapat persetujuan dari pimpinan divisi maka akan berdampak pada kerugian operasional bank karena akan meningkatkan beban bank yang tidak dianggarkan sebelumnya sehingga akan menimbulkan overbudget. Dalam hal ini, maka diperlukannya sistem pengendalian internal untuk menekan atau meminimalisir terjadinya overbudget yaitu dengan keharusan melakukan penyelesaian Persekot sebelum 10 hari kerja. Selain itu, pengambilan uang Persekot harus dilakukan oleh Asisten Administrasi Umum atas persetujuan Supervisor Administrasi Umum dan Pimpinan Kantor Cabang. Penggunaan Persekot harus diawasi oleh Supervisor Administrasi Umum dan disertai nota-nota transaksi sebagai bukti atas penggunaan uang Persekot tersebut.

Sejauh ini dalam konteks kerugian operasional perusahaan, PT Bank Negara Indonesia (Persero) Tbk KCU Magelang belum pernah mencatat terjadinya kerugian akibat penggunaan Persekot. Hal yang menyebabkan tidak disetujuinya Persekot yaitu 
ketika pimpinan divisi tidak mau menandatangani dan menyetujui laporan pertanggungjawaban atas penggunaan Persekot (Reimbursement). Sebagai contoh, Divisi Pemasaran pada PT Bank Negara Indonesia (Persero) Tbk Cabang Yogyakarta akan mengadakan seminar pemasaran dan bisnis di Magelang. Dalam menunjang kegiatan tersebut, PT Bank Negara Indonesia (Persero) Tbk KCU Magelang memberikan support penggunaan Persekot untuk biaya pengadaan seminar. Dengan kata lain, PT Bank Negara Indonesia (Persero) Tbk KCU Magelang membiayai pengeluaran operasional PT Bank Negara Indonesia (Persero) Tbk Cabang Yogyakarta. Persekot yang diberikan kepada Divisi Pemasaran yaitu sebesar Rp8000.000,00. Selanjutnya, dalam mengelola Persekot tersebut, Divisi Pemasaran harus mengumpulkan bukti-bukti transaksi pengeluaran atas penggunaan Persekot. Bukti-bukti tersebut yang nantinya akan digunakan sebagai laporan pertanggungjawaban atas penggunaan Persekot (Reimbursement) oleh PT Bank Negara Indonesia (Persero) Tbk KCU Magelang. Reimburstment tersebut harus disetujui dan ditandatangani terlebih dahulu oleh kepala Divisi Pemasaran PT Bank Negara Indonesia (Persero) Tbk Cabang Yogyakarta sebelum transaksi-transaksi dijurnal oleh PT Bank Negara Indonesia (Persero) Tbk KCU Magelang. Jika kepala Divisi Pemasaran PT Bank Negara Indonesia (Persero) Tbk Cabang Yogyakarta tidak menyetujui dan tidak menandatangani Reimbursement tersebut, maka penggunaan Persekot menjadi beban kerugian PT Bank Negara Indonesia (Persero) Tbk KCU Magelang.

Pelaporan pada Persekot dilakukan dengan melakukan penyelesaian Persekot terlebih dahulu. Penyelesaian Persekot dilakukan dengan cara mengumpulkan nota-nota transaksi dan mengelompokkan serta menjurnalnya ke dalam pos-pos beban sesuai dengan transaksinya. Berdasarkan pos-pos beban tersebut, Persekot dilampiri dengan voucher ( Rekening Debet/Rekening Kredit ). Berdasarkan voucher tersebut Teller akan membuatkan Memo penggunaan Persekot. Selain itu, Peran kartu kendali atau Control Card juga sangat penting dalam menjaga stabilitas dan mengendalikan pengeluaran atau penggunaan Persekot. Voucher yang telah dibuat tersebut akan diregister ke dalam Control Card sesuai dengan pos-pos beban.

Sebagai pertanggungjawaban Persekot diselesaikan dengan mendebet rekening beban yang disesuaikan dengan transaksi atau penggunaannya. Mengembalikan saldo Rekening Persekot menjadi 0 atau negatif karena saldo awal Rekening Persekot dalam keadaan 0 atau negatif maka setelah penyelesaian Persekot, saldo harus 0 atau negatif seperti semula. Jika terjadi tidak disetujuinya laporan pertanggungjawaban atau Reimbursement terhadap penggunaan Persekot, maka Persekot tersebut akan menjadi beban perusahaan pada periode yang berjalan atau bisa disebut sebagai kerugian.

\section{KESIMPULAN}

Berdasarkan hasil penelitian dan pembahasan dapat disimpulkan bahwa penerapan dana kas kecil ( Petty Cash ) di PT Bank Negara Indonesia (Persero) Tbk KCU Magelang sedikit berbeda dengan kaidah akuntansi pada umumnya, yaitu dengan menggunakan Uang Muka/Persekot. Di PT Bank Negara Indonesia (Persero) Tbk KCU Magelang dana kas kecil ( Petty Cash) dibentuk dengan uang muka atau disebut dengan Persekot. Persekot ini digunakan untuk membiayai pengeluaran operasional bank yang sifatnya kecil dan segera seperti beban ATK, beban rapat kerja, biaya BBM Kendaraan, dan lain-lain. Dana untuk persekot ini diambil dari dana kas kecil ( Petty Cash) yang diambil dari Teller yang dipinjamkan sebagai uang muka operasional. 
Persekot memiliki batas maksimal penyelesaian selama 10 hari kerja. Jika selama 10 hari kerja tersebut Persekot tidak dapat diselesaikan atau tidak mendapat persetujuan dari pimpinan divisi maka akan berdampak pada kerugian operasional bank. Sebagai pertanggungjawaban Persekot diselesaikan dengan mendebet rekening beban yang disesuaikan dengan transaksi atau penggunaannya. Mengembalikan saldo Rekening Persekot menjadi 0 atau negatif seperti semula.

Beberapa Pengendalian Internal diterapkan di PT Bank Negara Indonesia (Persero) Tbk KCU Magelang guna mengatur internal perusahaan dan meminimalisis terjadinya kerugian. Pengendalian Internal yang paling utama adalah ketika tidak disetujuinya laporan pertanggungjawaban atau Reimburstmen maka akan dibebankan sebagai kerugian perusahaan. Hal yang dapat dilakukan untuk mencegah terjadinya ketidaksetujuan atas laporan pertanggungjawaban yaitu dengan cara melakukan konfirmasi awal atau perjanjian dengan pihak atau divisi terkait dalam penggunaan Persekot serta mengumpulkan setiap bukti transaksi atas penggunaan Persekot. Apabila hal tersebut masih terjadi maka yang akan bertanggungjawab atas kerugian adalah bank yang memberikan atau mengeluarkan Persekot untuk keperluan operasionalnya.

\section{DAFTAR PUSTAKA}

A., Hatta, M. \& Tianah , A., 2015. Pengembangan Sistem Pencatatan Pengeluaran Dana Kas Kecil Metode Imprest Fund System Berbasis Komputer di STMIK CIC Cirebon. Jurnal Digit, 5(1), pp. 89-102.

Darwis, D., Wahyuni, D. \& D., 2020. Sistem Informasi Akuntansi Pengolahan Dana Kas Kecil Menggunakan Metode Imprest Pada PT Sinar Sosro Bandarlampung. Jurnal Teknologi dan Sistem Informasi (JTSI), 1(1), pp. 15-21.

Fauzan, M., 2018. Sistem Pengendalian Intern Terhadap Fungsi Penerimaan Kas Pada PT. Bank Muamalat Indonesia Cabang Pematangsiantar. Jurnal Masharif alSyariah: Jurnal Ekonomi dan Perbankan Syariah, 3(2), pp. 5-25.

Grahito, P. \& S., 2015. Peranan Pengelolaan Kas Kecil Dalam Menunjang Operasional Pada PT. Fastfood Indonesia Tbk (Studi Kasus Pada Kentucky Fried Chicken Taman Topi Bogor). pp. 43-49.

Karlina, E., Ariandi, F., Humaeroh, S. D. \& Martiwi, R., 2019. Analisis Pelaksanaan Pencatatan Petty Cash (Kas Kecil) Pada PT MNI Entertainment Jakarta Pusat. Widya Cipta : Jurnal Sekretari dan Manajemen, 3(2), pp. 233-240.

Mahfiza, 2018. Penerapan Sistem Pengendalian Intern Kas dan Implikasinya Terhadap Kewajaran Pengelolaan Kas. Jurnal Al-Buhuts, 1(1), pp. 112-123.

Nurmalasari, G. A. \& AR, M. D., 2018. Analisis Prosedur Permintaan dan Pertanggungjawaban Uang Muka Kerja Dalam Upaya Peningkatan Pengendalian Intern (Studi Pada Perum Jasa Tirta I Kantor Pusat Malang). Jurnal Administrasi Bisnis, 61(1), pp. 11-19. 
Pratiwi, C. W., Natalia, A. \& Wiryani, S. P., 2016. Analisis Sistem Pengendalian Internal Penerimaan Kas Pada PT. XYZ. UG Jurnal, 10(12), pp. 15-20.

Puspasari, A., Suhendra, A. D. \& Kusnaeni, E., 2019. Pengendalian Internal Piutang Pada PT. Saurindotex Mandiri Bekasi. Jurnal Ilmiah MEA, 3(1), pp. 30-43.

Rivai, A. \& Pratiwi, N., 2016. Analisis Prosedur dan Sistem Pengendalian Internal Dana Kas Kecil Pada CV. Sumber Rejeki. JMBA - Jurnal Manajemen dan Bisnis, 2(1), pp. 1-8.

Sari, D. K., Budiwibowo, S. \& Astuti, E., 2018. Evaluasi Sistem Informasi Akuntansi Penggunaan dan Pengelolaan Petty Cash Pada PT Bank BRI Syariah KC Madiun. Forum Ilmiah Pendidikan Akuntansi.

Sari, F. I. \& Sutiyono, F., 2017. Sistem Pengendalian Internal Terhadap Pengelolaan Dana Kas Kecil pada PT Jasa Marga (Persero) Tbk Cabang Jakarta-Cikampek. Jurnal Mahasiswa Bina Insani, 2(1), pp. 87-94.

Zandra, R. A. P. \& Solikhah, Z., 2018. Efektivitas Pengendalian Internal Atas Transaksi Kas. Jurnal Kajian Akuntansi, 2(1), pp. 54-66. 